\title{
Pathogenesis of Eutypa lata in Grapevine: Identification of Virulence Factors and Biochemical Characterization of Cordon Dieback
}

\author{
P. E. Rolshausen, L. C. Greve, J. M. Labavitch, N. E. Mahoney, R. J. Molyneux, and W. D. Gubler
}

First, second, third, and sixth authors: University of California, Department of Plant Pathology, One Shields Avenue, Davis 95616; fourth and fifth authors: Western Regional Research Center, Agricultural Research Service, U.S. Department of Agriculture, 800 Buchanan Street, Albany, Berkeley CA.

Accepted for publication 17 September 2007.

\begin{abstract}
Rolshausen, P. E., Greve, L. C., Labavitch, J. M., Mahoney, N. E., Molyneux, R. J., and Gubler, W. D. 2008. Pathogenesis of Eutypa lata in grapevine: Identification of virulence factors and biochemical characterization of cordon dieback. Phytopathology 98:222-229.

Eutypa lata is a vascular pathogen of woody plants. In the present study we (i) determined which component(s) of the cell wall polymers were degraded in naturally infected grapevines and in artificially inoculated grape wood blocks; (ii) compared the pattern of wood decay in the tolerant grape cv. Merlot versus the susceptible cv. Cabernet Sauvignon;

targets of E. lata. Structural glucose and xylose of the hemicellulose fraction of the plant cell wall and starch were depleted in infected woods identically in both cultivars. Moreover, the more tolerant cv. Merlot always had more lignin in the wood than the susceptible cv. Cabernet Sauvignon, indicating that this polymer may play a role in disease resistance. In vitro assays demonstrated the production by $E$. lata of oxidases, glycosidases and starch degrading enzymes. Phytotoxic secondary metabolites were also produced but our data suggest that they may bind to the wood. Finally, we demonstrated that free glucose in liquid cultures repressed primary but not secondary metabolism.
\end{abstract} and (iii) identified secondary metabolites and hydrolytic enzymes expressed by E. lata during wood degradation. Biochemical analyses and a cytochemical study indicated that glucose-rich polymers were primary
Additional keywords: ascomycetes, fungi, gas chromatography, soft-rot, xylariales.
Eutypa lata (Pers:Fr.) Tul. and C. Tul (=E. armeniacae Hansf. and M. V. Carter) is a vascular pathogen of many plants worldwide $(10,11,12)$. The fungus is an economic threat to fruit and nut tree production. The cost to wine grape production alone in California has been estimated to be in excess of 260 million dollars per annum (41), primarily as a consequence of decreased yields, increased vineyard management costs, and reduced longevity of the grapevines (30).

$E$. lata spreads by means of ascospores and infects exposed vascular vessels, which usually occur as the result of pruning. The fungus subsequently invades the wood and kills its host over time by producing an array of toxins $(13,25,26,29,32,42,44)$ and cell wall degrading enzymes $(17,18,37)$. Vitis vinifera cultivars display differences in their susceptibility to E. lata and subsequent symptom development $(16,31)$, but no cultivar is known to be immune to infection.

Eutypa dieback is a slow perennial disease and symptoms usually appear after several years on older vines (8 to 10 years). Infected grapevines exhibit stunted shoots with shortened internodes, and small, chlorotic, cupped, tattered leaves with marginal necrosis and dead interveinal tissue. Foliar symptoms are best seen in the spring. Many of the flowers often dry before blooming and the berries that develop at the infected spur position are usually small and straggly in appearance. These foliar and fruit symptoms are believed to result from the direct effect of fungal metabolites. According to the current hypothesis, these phytotoxic

Corresponding author: W. D. Gubler; E-mail address: wdgubler@ucdavis.edu

doi:10.1094/PHYTO-98-2-0222

(c) 2008 The American Phytopathological Society secondary metabolites would be translocated from the infected cordon where E. lata resides, to the herbaceous tissues via the vessel elements. Cross sections of infected cordons show canker formation with a wedge-shaped brown area and occasionally streaks and flecks of darkened tissue in the live wood. The type of wood decay caused by E. lata is classified as a soft-rot (18).

The goal of this study was to gain a better understanding of the mechanisms of pathogenesis causing disease on grapevine. In the present study we (i) determined which component(s) of the cell wall polymers were degraded in naturally infected grapevines and artificially inoculated grapevine wood blocks, (ii) compared the pattern of degradation in the tolerant grape cv. Merlot and the susceptible cv. Cabernet Sauvignon, and (iii) identified secondary metabolites and hydrolytic enzymes expressed by E. lata during wood degradation.

\section{MATERIALS AND METHODS}

Fungal culture. E. lata isolate E31 was isolated from a canker of grapevine cv. Chenin Blanc in California. The fungus was stored at $4{ }^{\circ} \mathrm{C}$ in water and cultured on potato dextrose agar (PDA) before the onset of the experiments.

Field sampling. Grapevine wood samples originated from a vineyard located in Napa County in California. Grapevine cvs. Cabernet Sauvignon and Merlot were planted on AXR rootstock in 1986 and 1985, respectively. Twenty grapevines showing Eutypa dieback symptoms on the foliage were flagged in the spring of 2003. A $1 \mathrm{~cm}$ thick slice of wood showing wedge shaped cankers in the cordon adjacent to the flagged spur was cut off and brought to the laboratory. Moreover, healthy 1-year-old canes were sampled from the same cultivars during the dormant season in 2003 and were used for in vitro laboratory tests. 
Biochemical analyses of grapevine wood naturally infected with $\boldsymbol{E}$. lata. The bark of the wood samples was stripped away. The presence of E. lata in the wedge shaped cankers was detected by isolating from infected wood onto PDA medium amended with tetracycline. Fungi identified morphologically as E. lata were confirmed by polymerase chain reaction-restriction fragment length polymorphism (PCR-RFLP) (33). Five samples positive for $E$. lata and free of several other fungi known to cause wood decay in grapevines (i.e., Phomopsis viticola, Botryosphaeria spp., Phaeomoniella chlamydospora, Phaeoacremonium spp.) were selected for biochemical analyses. Three wood zones consisting of the healthy wood (living sapwood), the canker (dead sapwood) and the marginal wood from canker lesions were separated from each other. Wood fractions were ground to a fine powder using a stainless steel ball mill grinder (Crescent Dental, M.F.G. Co., Lyons, IL). The wood powder was washed at $50^{\circ} \mathrm{C}$ overnight, three times each with water, water:methanol (1:1), and methanol. Each extraction step was carried out by stirring $1 \mathrm{~g}$ of wood powder in $50 \mathrm{ml}$ of extractant overnight followed by centrifugation to pellet the residue and decant the supernatant. Those extractions removed soluble non-cell-wall compounds (primarily low molecular weight sugars) that could have interfered with subsequent analyses of the polymeric wood constituents. The extracted wood powder was dried and stored in an incubator at $50^{\circ} \mathrm{C}$. The amount of material in each fraction was reported as percentage dry weight (PDW) and was calculated on the basis of the total dry weight (TDW) of the sample.

The polymeric carbohydrate in the insoluble crude wood cell wall fraction was analyzed in $5 \mathrm{mg}$ of washed wood powder (TDW). Samples were hydrolyzed for $1 \mathrm{~h}$ at $120^{\circ} \mathrm{C}$ with $1 \mathrm{ml}$ of $2 \mathrm{~N}$ trifluoroacetic acid (TFA) containing an internal standard (myo-inositol at $100 \mu \mathrm{g} / \mathrm{ml}$ ) (3). The TFA-soluble fractions were collected as the supernatant following centrifugation at 3,000 $\times g$. The insoluble pellet (TFA-insoluble fraction) was re-suspended in methanol, shaken briefly, and re-centrifuged. The supernatant was added to the previously collected TFA-soluble material. The pellet was hydrolyzed a second time with TFA. The second TFA-soluble fraction was collected (as above) and combined with the first. Samples were evaporated to dryness in a stream of filtered air and converted to alditol acetates $(3,6)$ that were analyzed by gas chromatography (45).

Cellulose content of the wood powder was determined by colorimetric assay (14) of the TFA-insoluble pellet of the wood fraction after dissolution in $5 \mathrm{ml}$ of $67 \%$ sulfuric acid (45).

Lignin content in the wood samples was analyzed in $20 \mathrm{mg}$ of the dried wood powder using the thioglycolic acid assay as described by Doster and Bostock (15). The absorbance was measured by spectrophotometer at $280 \mathrm{~nm}$.

Pectin content in wood samples was analyzed in $5 \mathrm{mg}$ of washed wood powder as described by Ahmed and Labavitch (2) with a colorimetric assay described by Blumenkrantz and AsboeHansen (8) with a polygalacturonic acid solution used as a standard. The absorbance was measured by spectrophotometer at $520 \mathrm{~nm}$.

The data were analyzed statistically as above using a repeated measure analysis of variance (ANOVA) to determine if the cell wall components were degraded evenly overtime in cvs. Merlot and Cabernet Sauvignon. All data analysis was performed using SAS (version 9.1, SAS Institute Inc., Cary, NC).

Biochemical analyses of grapevine wood blocks artificially inoculated with $\boldsymbol{E}$. lata. Inter-nodal segments, $4 \mathrm{~cm}$ in length, were cut from 1-year-old grapevine canes, and bark was shaved off with a knife. Thirty samples per cultivar were selected and were autoclaved twice. Ten wood samples were used for cytochemical study. Five inter-nodal segments were used to identify the composition of pectin, cellulose, lignin, and polymeric carbohydrate of healthy wood of each cultivar. The remaining 15 inter-nodal segments were wetted with sterile water, intro- duced into individual glass tubes under aseptic conditions, and inoculated with a mycelial culture of E. lata isolate E31 drawn from the outer margin of a PDA culture. Tubes were sealed with cotton and tube caps in order to maintain sterility. Five replicates of inoculated cuttings per cultivar were sampled randomly after 6 , 12 , and 18 months. Chips of wood were removed from inoculated segments in aseptic conditions and plated on PDA medium in order to assure that no contamination had occurred and that only E. lata was recovered from wood tissue. Wood segments were then dried in the oven overnight at $50^{\circ} \mathrm{C}$ and dry weights were recorded. Wood was ground to a fine powder and washed as described above. However, each water and water:methanol fraction was kept separate in order to analyze the composition of soluble material. The remainder of the wood powder (nonsoluble components) was stored in an incubator at $50^{\circ} \mathrm{C}$ and subsequently used for cell wall constituent analysis, as described above. Results are calculated from analysis of loss in wood block dry mass and analysis of percent dry weight of cell wall constituents identified in wood powders prepared from sampled infected wood blocks as followed; percentage of the original amount of cell wall constituent remaining at a given time $X=100-\{[\mathrm{A} 0-(\mathrm{AX} \times$ $\mathrm{BX})] / \mathrm{A} 0 \times 100\}$, where $\mathrm{A} 0$ is the PDW of cell wall constituent $\mathrm{A}$ before inoculation, $\mathrm{AX}$ is the PDW of the cell wall constituent $\mathrm{A}$ at time $\mathrm{X}$, and $\mathrm{BX}$ is the total dry weight loss at time $\mathrm{X}$.

The water and water:methanol soluble fractions were evaporated to dryness in a stream of filtered air and re-suspended in $4 \mathrm{ml}$ of water and water/methanol, respectively. The total amount of sugars in these soluble fractions was determined by sampling two aliquots of $100 \mu \mathrm{l}$ of each fraction and evaporating them to dryness in a stream of filtered air. One of these samples was hydrolyzed using TFA and the other was not. Monosaccharides in the hydrolyzed and unhydrolyzed samples were analyzed by gas chromatography. The sugar composition of the total soluble polyand oligosaccharides in the water and water:methanol fractions was determined after subtracting the amount of each monosaccharide measured in the respective unhydrolyzed sample fractions.

The presence of starch in healthy and infected wood samples was determined by stain reaction. Five healthy (before the onset of fungal decay) and five 18-month-old infected wood sticks were stained with a drop of $\mathrm{I}_{2} \mathrm{KI}$ ( $2 \%$ of each $\mathrm{I}_{2}$ and $\mathrm{KI}$ in distilled water) rinsed in distilled water and examined under a stereoscope (model LEICA MZ95).

The data were analyzed statistically to determine if the grape cultivar had an impact on cell wall degradation by $E$. lata over time.

Biochemical analyses of $\boldsymbol{E}$. lata cell wall. Because some of the sugars identified in the powders prepared from infected grapevine wood might have originated either from E. lata or wood cell walls, the neutral sugar and amino sugar composition of the E. lata cell wall was determined in order to improve the identification of components of the wood that had been depleted due to fungal activity. E. lata isolate E31 was grown in the defined liquid medium of Eriksson and Petersson (19), supplemented with 1\% glucose for 4 weeks at room temperature. Mycelium was filtered through Whatman glass fiber paper (GF/A paper, 125-mm diameter) and washed overnight with $100 \mathrm{ml}$ of buffer $(1 \mathrm{M} \mathrm{NaCl}$ in $0.1 \mathrm{M} \mathrm{Na}$ acetate, $\mathrm{pH}$ 5). The buffer-washed mycelium was filtered, as above, and dried with a lyophilizer model Edwards super modulyo (AIR Refrigeration Services, Inc., Sacramento, CA). The PDW of sugars and amino sugars in the fungal cell wall fraction was analyzed using $5 \mathrm{mg}$ samples of dried washed mycelium. Glucosamine and galactosamine standard solutions $\left(500 \mu \mathrm{l} / \mathrm{ml}\right.$ in distilled $\mathrm{H}_{2} \mathrm{O}$ ) were processed simultaneously with the samples after being evaporated to dryness in a stream of filtered air in order to determine correction factors for amino sugars from the fungal cell wall. A total of $500 \mu \mathrm{l}$ of $4 \mathrm{M} \mathrm{HCl}$ was added to each sample and oxygen was removed from the tube by flushing with nitrogen to avoid oxidation of amino sugars during the hydrolysis. Samples were heated at $100^{\circ} \mathrm{C}$ for $18 \mathrm{~h}$ and 
evaporated to dryness as previously described. They were then washed with $500 \mu \mathrm{l}$ of distilled $\mathrm{H}_{2} \mathrm{O}$ twice and evaporated to dryness with air to assure removal of all $\mathrm{HCl}$. A total of $100 \mu \mathrm{l}$ of $\mathrm{dH}_{2} \mathrm{O}, 25 \mu \mathrm{l}$ of $5 \%$ acetic anhydride, and $25 \mu \mathrm{l}$ of a saturated sodium bicarbonate solution was added to the samples which were incubated at room temperature for $3 \mathrm{~min}$. The additions of acetic anhydride and saturated sodium bicarbonate solution were repeated two more times. After the second time, samples were left at room temperature for $20 \mathrm{~min}$ and then heated at $100^{\circ} \mathrm{C}$ for 4 min and blown to dryness with air. Sugars were transformed to alditol acetate derivatives using sodium borodeuteride in the reduction step, prior to analysis by gas chromatography-mass spectrometry (45).

Identification of virulence factors produced by $E$. lata. E. lata was cultured in flasks at room temperature $\left(20\right.$ to $\left.22^{\circ} \mathrm{C}\right)$ in $50 \mathrm{ml}$ of three different liquid culture media and production of secondary metabolites and enzymes was measured after 1 and 6 months. The basis of these media was Eriksson and Petersson medium (19). Control medium was supplemented with $0.2 \%$ glucose, the second medium contained $0.2 \%$ glucose and $1 \%$ water and water:methanol washed sterile wood powder of 1-year-old cv. Cabernet Sauvignon, and the last medium contained only $1 \%$ of the same wood powder. Each liquid culture was inoculated with a $1 \mathrm{~cm}$ plug of E. lata isolate E31 taken from the outer margin of a week-old PDA culture. Cultures were continuously shaken at $100 \mathrm{rpm}$. Cultures were sampled after 1 and 6 months of growth and were filtered through Whatman GF/A paper (125-mm diameter). The wood powder remaining was washed overnight with $50 \mathrm{ml}$ of a buffer solution $(1 \mathrm{M} \mathrm{NaCl}$ and $0.1 \mathrm{M} \mathrm{Na}$ acetate, $\mathrm{pH}$ $5)$. The buffer solution was then filtered as previously described and the filtrate was collected and combined with the first. The filtrates were all adjusted to $150 \mathrm{ml}$ of total volume with buffer. A total of $50 \mathrm{ml}$ (sample A) was used to measure secondary metabolite production and soluble neutral sugars. The remaining $100 \mathrm{ml}$ (sample B) was used to measure enzymatic activity.

Analysis of residual soluble sugars in culture medium. Two aliquots of $100 \mu \mathrm{l}$ were taken from sample A. Samples were evaporated to dryness in a stream of filtered air. One aliquot was hydrolyzed once with 2 N TFA as previously described, while the other aliquot was left unhydrolyzed in order to identify the monosaccharides present in each fraction. Sugars were transformed to alditol acetates and analyzed by gas chromatography. The sugar compositions of the oligo- and polysaccharides soluble in the liquid culture media were determined after subtracting the amount of each monosaccharide measured in the respective unhydrolyzed samples from the culture filtrates.

Identification of secondary metabolites produced by $\boldsymbol{E}$. lata. The remainder of sample A was partitioned with an equal volume of ethyl ether. The ether was concentrated under reduced pressure, the dried extract dissolved in methanol $(1 \mathrm{ml})$ and filtered through a $0.45 \mu \mathrm{m}$ nylon syringe filter. Aliquots $(20 \mu \mathrm{l})$ were quantitatively analyzed for fungal metabolites by reverse-phase HPLC (on a $250 \mathrm{~mm} \times 4.6 \mathrm{~mm}$, i.d., Varian Microsorb 100-5 C18 column) using a mobile phase gradient of $100 \%$ water containing $0.5 \%$ acetic acid to $100 \%$ acetonitrile over $30 \mathrm{~min}$ at a flow of
$1 \mathrm{ml} / \mathrm{min}$ with detection at $254 \mathrm{~nm}$ using a photodiode array detector (Agilent 1100) (26).

Identification of enzymes produced by $\boldsymbol{E}$. lata. Sample B was dialyzed in 6,000 to 8,000 MW cut-off tubing (Fisher Scientific) for $12 \mathrm{~h}$ at $4^{\circ} \mathrm{C}$ in 4 liters of a $25 \mathrm{mM}$ sodium acetate, $\mathrm{pH} 6$ solution, with two buffer changes in order to remove low molecular compounds, primarily sugars. Solutions were then concentrated at $4^{\circ} \mathrm{C}$ by dialysis against polyethylene glycol size 15,000 to 20,000 MW (Sigma) and were adjusted to a volume of $20 \mathrm{ml}$ with a buffer $(50 \mathrm{mM}$ of sodium acetate $\mathrm{pH}$ 6). Enzymatic activities were assessed in concentrated filtrate solutions.

Starch degrading activity was measured using a radial diffusion assay (43). A solution with $0.05 \mathrm{M}$ of sodium acetate $\mathrm{pH} 5,0.03 \%$ soluble starch (Sigma) and 1\% agarose (Sigma) was made, microwaved until total dissolution of the starch and agarose, and poured into a square Plexiglass frame. After the medium had solidified, wells were made by removing a plug of the medium, and $100 \mu \mathrm{l}$ of the concentrated raw enzymatic filtrate was pipetted into the wells. Plates were covered, sealed, and incubated at $37^{\circ} \mathrm{C}$ overnight. Plates were stained with $\mathrm{I}_{2} \mathrm{KI}$ for $5 \mathrm{~min}$ and washed several times with distilled water and evaluated under bright light. Positive enzyme activity was detected by the formation of an unstained halo around the wells representing the area where the starch had been digested.

Glycosidase activities were determined by measuring the amount of $p$-nitrophenol released from $p$-nitrophenyl glycoside substrates (23). Assays contained $1 \mathrm{ml}$ of substrate at $1 \mathrm{mg} / \mathrm{ml}$, $1 \mathrm{ml}$ of enzyme (culture media concentrate) and $1 \mathrm{ml}$ of buffer (50 mM sodium acetate, $\mathrm{pH} \mathrm{6}$ ), and were incubated at $37^{\circ} \mathrm{C}$ for $8 \mathrm{~h}$. After $0,1,2,4$, and $8 \mathrm{~h}$ of incubation, $0.5 \mathrm{ml}$ of each reaction mixture was subsampled and the reaction was stopped by the addition of $1 \mathrm{ml}$ of $1 \mathrm{~N} \mathrm{NH}_{4} \mathrm{OH}$. The $p$-nitrophenol released was measured by the increase in absorbance at $400 \mathrm{~nm}$, with a solution of $p$-nitrophenol used for a standard curve. One unit of activity equals $1 \mu \mathrm{mol}$ of substrate hydrolyzed per min at $37^{\circ} \mathrm{C}$. The $p$-nitrophenyl substrates used for glycosidase determination were $\alpha$ - and $\beta$-D-galactopyranoside, $\alpha$ - and $\beta$-D-glucopyranoside, $\alpha$-L-arabinofuranoside, $\alpha$-D-mannopyranoside, $\alpha$-L-rhamnopyranoside, and $\alpha$-D-xylopyranoside.

Phenol oxidase activity was measured on petri plates of Bavendamm's medium, containing $0.5 \%$ tannic acid and $0.5 \%$ gallic acid amended in malt agar (5). Wells were made by removing a plug of the medium, and $100 \mu \mathrm{l}$ of the enzyme (culture media concentrate) was pipetted into the wells. In addition, a 0.5-cm-diameter plug of agar was drawn from the edge of a culture of E. lata isolate E31 and placed on Bavendamm's medium. Plates were incubated at room temperature for 7 days. Browning of the medium was rated as a positive indication of oxidation (i.e., production of phenol oxidase).

\section{RESULTS}

The distribution of major structural components of the cell wall of healthy 1-year-old, and 17- and 18-year-old wood samples from cvs. Cabernet Sauvignon and Merlot are shown in Table 1.

TABLE 1. Percent dry weight of major structural components of cell walls (polymeric carbohydrate, cellulose, lignin, pectin) in grapevine wood of two ages for cvs. Merlot and Cabernet Sauvignon

\begin{tabular}{|c|c|c|c|c|}
\hline \multirow[b]{3}{*}{ Cell wall component } & \multicolumn{4}{|c|}{ Cultivar } \\
\hline & \multicolumn{2}{|c|}{ Merlot } & \multicolumn{2}{|c|}{ Cabernet sauvignon } \\
\hline & 1 year old & 18 years old & 1 year old & 17 years old \\
\hline Lignin & $12.2 \pm 0.8^{\mathrm{a}}$ & $15.8 \pm 1.6$ & $11.7 \pm 0.7$ & $13.3 \pm 0.6$ \\
\hline Pectin & $5.4 \pm 0.7$ & $4.3 \pm 0.6$ & $6.1 \pm 0.5$ & $4.7 \pm 0.3$ \\
\hline Cellulose & $32.1 \pm 1.7$ & $35.8 \pm 1.8$ & $30.0 \pm 2.9$ & $36.7 \pm 4.5$ \\
\hline Polymeric carbohydrate & $35.1 \pm 2$ & $37.1 \pm 3.1$ & $35.3 \pm 3.3$ & $36.0 \pm 4.2$ \\
\hline
\end{tabular}

a Five replicates were used for each measurement. Variance represents standard deviation.

b Nonsoluble in water and water/methanol, soluble upon trifluoroacetic acid hydrolysis. 
Analysis of naturally infected grapevines indicated that tissues were more lignified at the margin of the infection and inside the canker for both cultivars in comparison to healthy wood. Lignin levels were always higher in Merlot in comparison to Cabernet Sauvignon (Fig. 1). Statistical analyses indicated significant $(P=$ $0.05)$ cultivar differences for the amount of percent dry weight lignin, highlighting the importance of this compound in the grapevine/E. lata interaction. No disease-related depletion of cellulose or pectin was measured in either cultivar (data not shown). However, the glucose-rich polymeric carbohydrate fraction (i.e., glucose released upon TFA hydrolysis of washed-wood powders) of the wood was depleted similarly in both cultivars (Fig. 2).

In artificially inoculated grapevine wood, the loss of wood mass due to the action of E. lata was observed at 6 month intervals, with a gradual decrease at each sampling reaching a low of

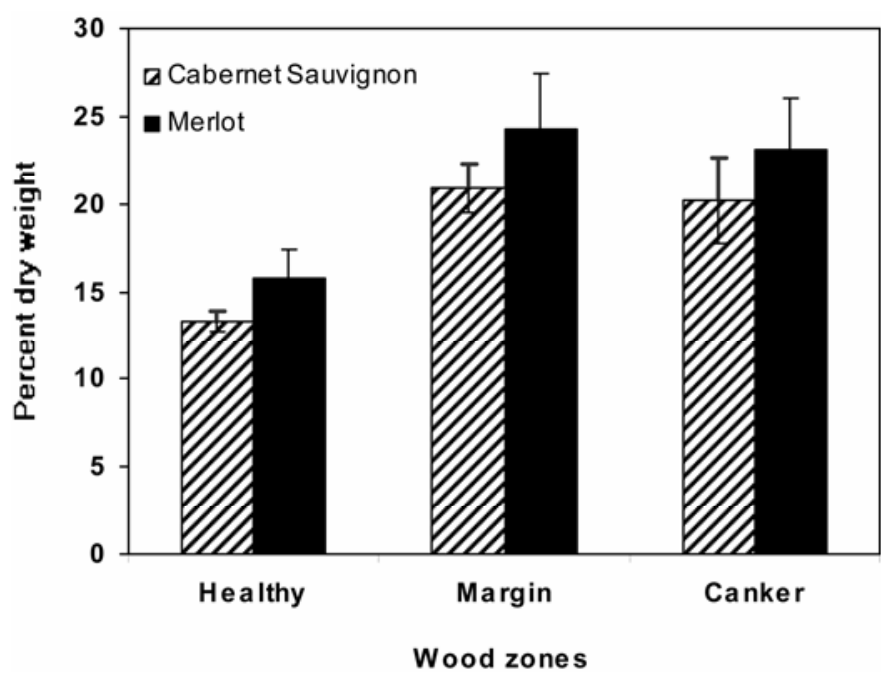

Fig. 1. Percent dry weight of lignin in three wood zones of grapevine cvs. Merlot and Cabernet Sauvignon. The three wood zones represent the healthy wood, the decayed wood, and the margin of the decayed wood. Eutypa lata was recovered from the margin and within the decayed wood. Wood samples were from 18- and 17-year-old grapes for Merlot and Cabernet Sauvignon, respectively. These results were based on five replicates. Bars represent the standard deviation.

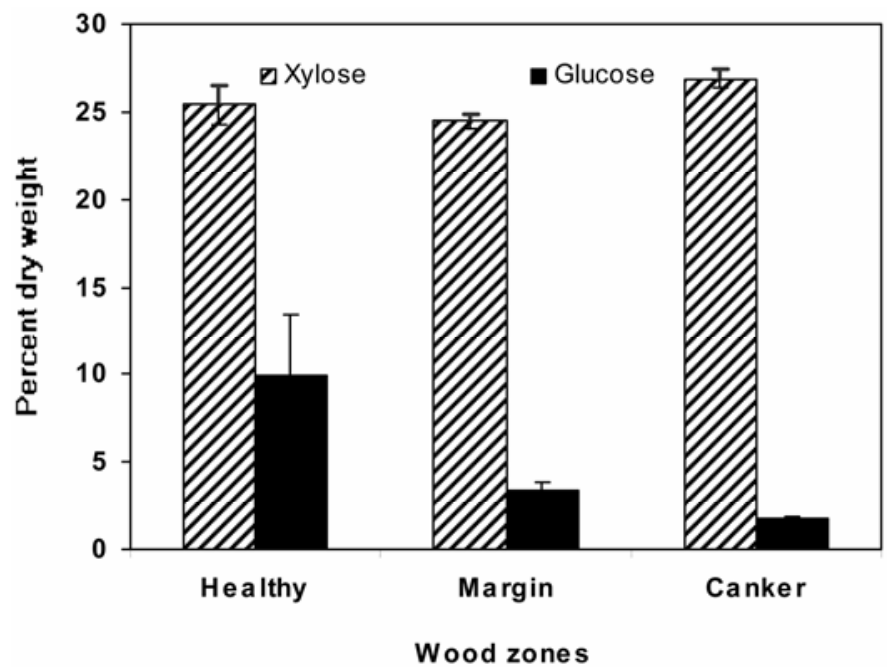

Fig. 2. Percent dry weight of hemicellulosic xylose and glucose measured in three wood zones of a 17-year-old cv. Cabernet Sauvignon grapevine. The three wood zones represent the healthy wood, the decayed wood, and the margin of the decayed wood. Eutypa lata was recovered from the margin and within the decayed wood. These results were based on five replicates. Bars represent the standard deviation. about $23 \%$ after 18 months in both cultivars (Fig. 3). Statistical analyses indicated significant $(P=0.05)$ cultivar differences for loss of dry weight over time. However, the measured dry weight of inoculated wood also included the fungal biomass associated with wood tissue, undoubtedly causing an underestimate of the true cell wall loss from the wood mass, which may have also interfered with the statistical analysis.

The most severe relative losses of cell wall components in the artificially inoculated wood occurred with the polymeric carbohydrates component of the cell wall in both cultivars. This loss was the result of a decrease in the xylose (25\%) and the glucan(s) in this fraction (90\%) (Fig. 4). Woody tissues can contain stored

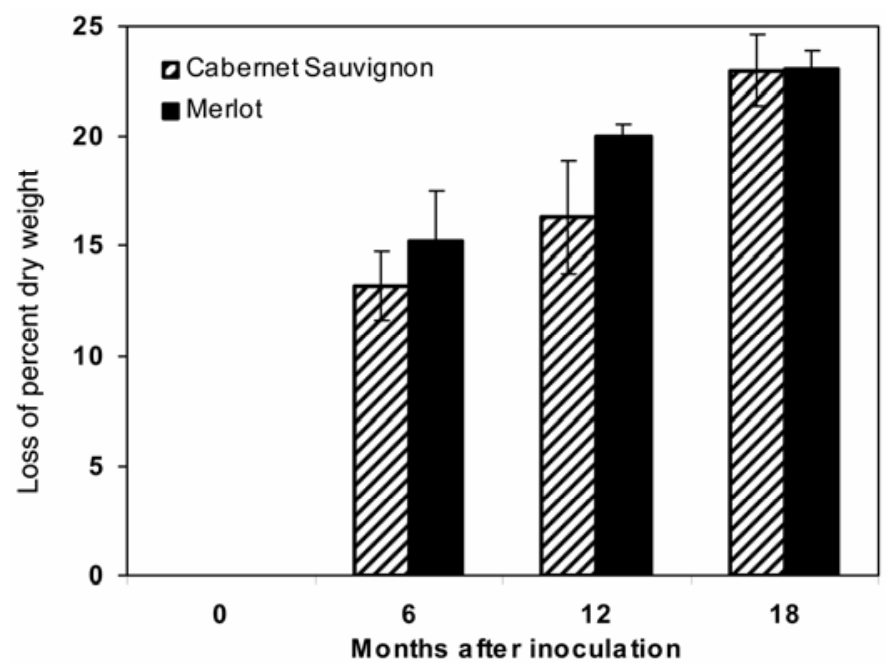

Fig. 3. Evaluation of the loss of total dry weight of 1-year-old inter-nodal wood segments from cvs. Cabernet Sauvignon and Merlot infected by Eutypa lata in vitro. Results are presented as percentages of wood dry weight. Measurements were recorded before the onset of fungal decay and every 6 months for 18 months. These results were based on five replicates. Bars represent the standard deviation.

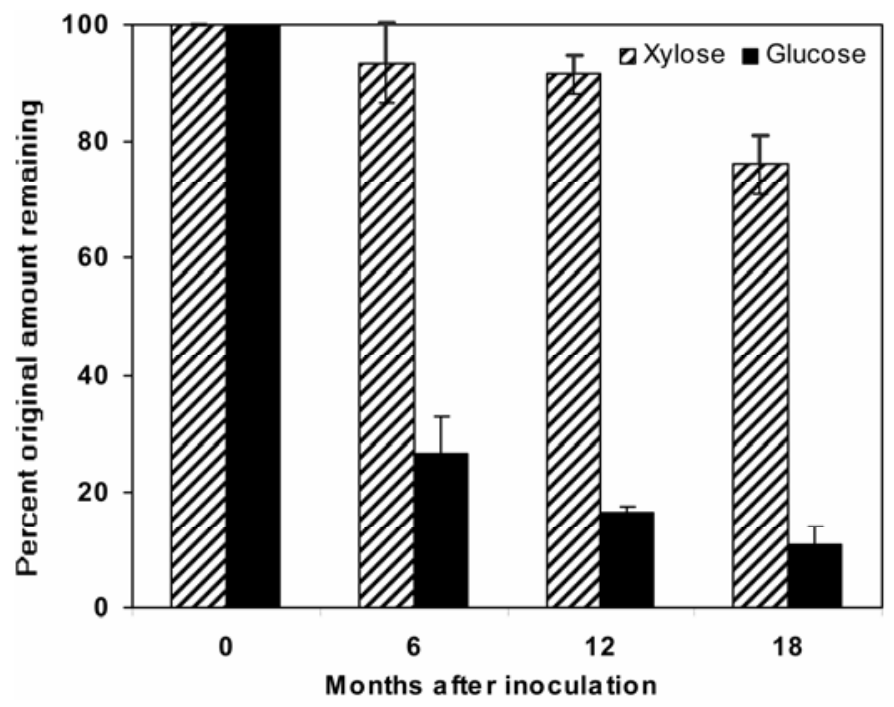

Fig. 4. Evaluation of the loss of hemicellulosic xylose and glucose from 1-year-old inter-nodal wood segments cv. Merlot infected by Eutypa lata in vitro. Results are presented as percentage of the original amount of xylose and glucose present in initial wood block samples remaining after fungal degradation for the indicated times. Measurements were recorded prior to inoculation and every 6 months for 18 months. Results are calculated from analysis of loss in wood block dry mass (Fig. 3) and analysis of percent dry weight of xylose and glucose identified in wood powders prepared from sampled infected wood blocks. These results were based on five replicates. Bars represent the standard deviation. 
carbohydrate reserves that include starch. Our samples were not treated to remove the starch "nonstructural" carbohydrate fraction. Starch granules do not become soluble in water or water/ methanol and therefore were encountered in the GC-measured neutral sugar of the washed cell wall powders. The starch-specific iodine stain indicated a strong positive reaction in wood samples from healthy vines, but a negative reaction after 18 months of fungal activity (data not shown), suggesting that E. lata can metabolize starch stored in wood. Lignin content was also noticeably depleted but only after 6 months (Fig. 5), suggesting lignolytic abilities of E. lata. Lignin increased in the last 12 months perhaps due to the greater relative loss of hemicellulose and/or the decrease of fungal biomass on the wood segments. Statistical analyses indicated significant $(P=0.05)$ cultivar difference for the percent of the original amount of lignin remaining after fungal activity, The amount of cell wall lignin remaining was higher for cv. Merlot than cv. Cabernet Sauvignon.

The analysis of the sugars in the water and water/methanol extracts of artificially inoculated wood sticks indicated a depletion of these soluble carbohydrates (Fig. 6). In healthy wood, most of the sugar in the extracts was accounted for by glucose that was linked into disaccharides or larger molecules. After 6 months of fungal degradation, xylose and the rest of the neutral sugars increased in the soluble fraction. After 12 and 18 months, xylose was gradually depleted, while monosaccharide arabinose and mannose reached measurable levels.

The analysis of E. lata cell wall detected glucose, mannose, galactose, and glucosamine. However, the proportion of each sugar and amino sugar measured in the fungal cell wall was variable in duplicate analyses and therefore is not presented here.

Mycelial growth of E. lata isolates was very slow in the control liquid medium, whereas the fungus quickly colonized woodsupplemented media. Of the activities assayed in filtered culture medium, only $\beta$-D-glucosidase was detected in the standard medium enriched with glucose (Table 2). Addition of wood powder to this medium enhanced the activity of $\beta$-D-glucosidase as well as expression of other glycosidases including $\alpha$-D-xylosidase and $\alpha$-D-glucosidase. Moreover, the absence of glucose in the wood-enriched medium also increased the recovered activity of the glycosidases mentioned previously and of other sets of

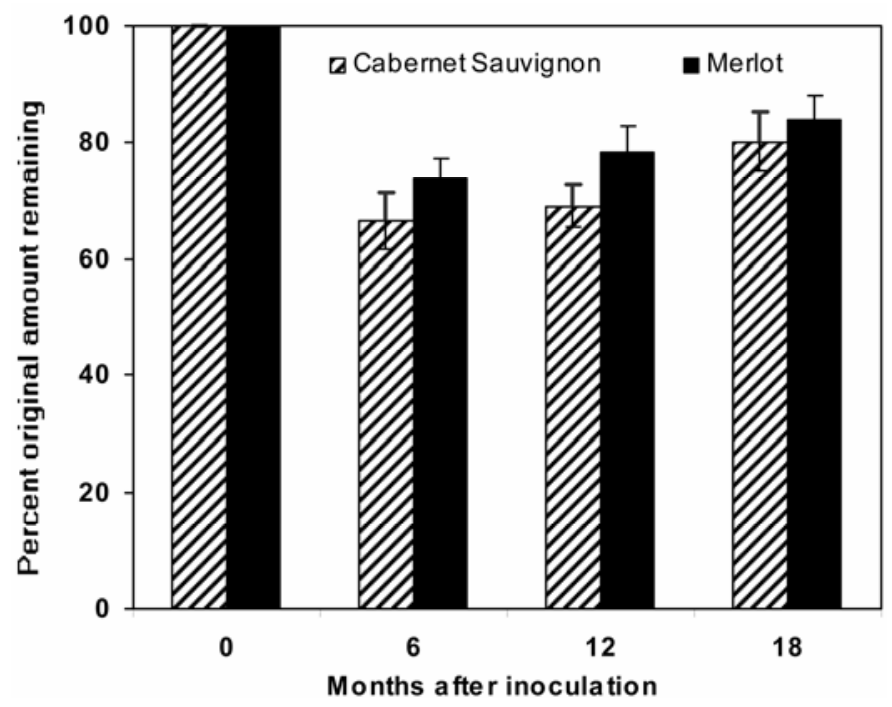

Fig. 5. Evaluation of the loss of lignin from 1-year-old inter-nodal wood segments from cvs. Cabernet Sauvignon and Merlot infected by Eutypa lata in vitro. Results are presented as percentage of the original amount of lignin present in initiate wood block samples remaining after fungal degradation for the indicated times. Measurements were recorded prior to inoculation and every 6 months for 18 months. The basis for the calculations is described in the legend for Figure 4. These results were based on five replicates. Bars represent the standard deviation. enzymes including $\beta$ - and $\alpha$-D-galactosidase. The radial diffusion assay also indicated that starch-degrading enzymes were expressed within 1 month of E. lata inoculation of the glucose-free wood-enriched liquid culture (Fig. 7). No or low $(<0.1 \mu \mathrm{mol} / \mathrm{min})$ activities of $\alpha$-L-arabinosidase, $\alpha$-D-mannosidase, or $\alpha$-L-rhamnosidase were detected in any cultures at any time. The Bavendamm's test indicated that no phenol oxidase activities were detected in the concentrated enzyme solution from all three liquid media. However, when E. lata isolate E31 was grown directly on Bavendamm's media, browning of tannic and gallic acids occurred, suggesting that phenol oxidase enzymes are expressed by the fungus.

The analysis of soluble sugars from liquid cultures indicated that the added glucose was totally depleted after 6 months of fungal growth. After 1 month, the depletion was faster in the wood-enriched medium $(92 \% \pm 2$ of the total glucose) than in wood-free medium $(67 \% \pm 1$ of the total glucose) (data not shown).

Finally, four secondary metabolites (eutypinol, eulatachromene, eutypine, and eutypic acid) were found at very low concentrations in the sugar medium (Table 3). The concentration of these metabolites built up over time. Eutypinol and eutypine were detected only after 1 month in the wood and sugar medium but not after 6 months. No metabolites were detected in the wood medium.

\section{DISCUSSION}

The type of decay caused by E. lata on wood is classified as a soft-rot (18). The term soft-rot was first used by Savory (36) to characterize the decay based on the soft appearance of the wood surfaces after decay in water-logged conditions. Today, soft-rot is a term used to describe all forms of decay caused by Ascomycetes and Fungi Imperfecti (7). The pattern of degradation differs from brown-rot and white-rot caused by Basidiomycetes $(7,28)$. On Angiosperms, soft-rot decay is characterized by erosion of the cell walls from the cell lumen towards the pectin-rich middle lamellae. The secondary wall layers ( $\mathrm{S}_{2}$ layer especially) are degraded but the attack does not progress to the middle lamellae (7). Photomicrographs of grapevine cell walls infected with $E$. lata

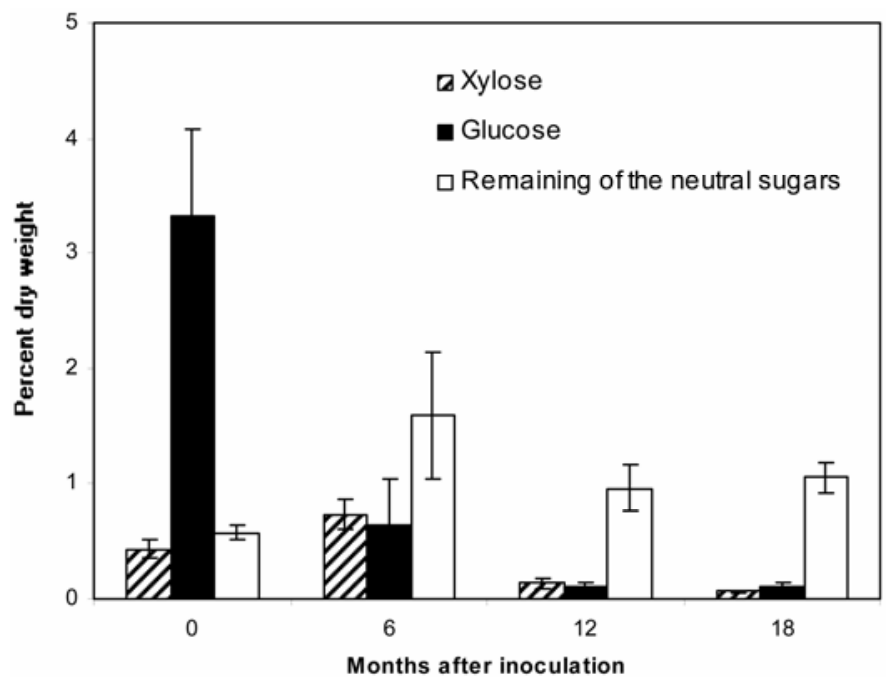

Fig. 6. Evaluation of the changes in vitro in the amounts of the low molecular weight sugars solubilized by water and water:methanol extraction of wood powders prepared from woody 1-year-old Eutypa lata infected segments of cv. Merlot. Sugars represented are glucose, xylose, and the remaining of the neutral sugars. Results are presented as percentage of dry weight of sampled infected wood blocks. Measurements were recorded prior to inoculation and every 6 months for 18 months. These results were based on five replicates. Bars represent the standard deviation. 
supported this pattern of degradation (35). Soft-rot fungi are reported to primarily degrade the carbohydrate components of the wall and lignin to a lesser extent, depending on the fungal species $(7,20,46)$. Some members of the Xylariaceae and Diatrypaceae (Xylariales, Ascomycetes) have been shown to possess strong wood decay abilities in comparison to other soft-rot fungi (46). Our data present the first report of the wood decay ability of E. lata, a member of this group of fungi. The pattern of degradation reported here with E. lata is consistent with the expectations for a soft-rot fungus.

The determination of grapevine cell wall polymers degraded during $E$. lata activity was impaired by the presence of fungal walls in the analyzed samples. The different wood washing steps may not have removed all the mycelium present in infected wood walls, and mycelium may also have contaminated the water and water-methanol extracts with soluble sugars of fungal origin. Our results indicated that glucose, mannose, galactose, and glucosamine were components of $E$. lata cell walls. The glucosamine fraction of fungal walls might have been encountered in the glucose pools of the analyses because the amine function of this product is commonly oxidized during the TFA hydrolysis at $120^{\circ} \mathrm{C}$ in the presence of oxygen. The results of fungal cell wall composition for E. lata are supported by other published work $(4,9,24)$.

Our examination of the polymeric carbohydrates (i.e., sugars released upon TFA hdrolysis of wood powders that had been washed in water and water:methanol to remove soluble sugars) in healthy and infected wood makes it clear that there is a selective removal of glucose-rich components. The analyses of naturally and artificially infected wood revealed that nonstructural (mostly starch) and structural (hemicellulosic) glucans are primary targets of E. lata. The extent of glucose depletion increased with time (i.e., internal versus marginal cankers, 18 versus 6 months of decay). Our cytochemical test indicated that starch was completely depleted after 18 months of fungal activity. Woody tissues often contain stored carbohydrate reserves such as starch. In grapevines, starch is stored in large plastids in xylem parenchyma cells and rays (35), and starch amounts vary during the year depending on the growth stage of the plant (47). Our data indicating that stored starch is lost during E. lata development in grapevines is consistent with report of Rudelle et al. (35) as well as with other woody tissues infected with other decay fungi $(1,27,40)$. Starch may serve as an energy reserve for hosts as they attempt to defend themselves against the invading organism

TABLE 2. Enzyme activities ( $\mu \mathrm{Mol} . \mathrm{min}^{-1}$ ) of Eutypa lata isolate (E31) in concentrated solution $(20 \mathrm{ml})$ expressed after 1 and 6 months of growth in three liquid media

\begin{tabular}{|c|c|c|c|c|c|c|}
\hline \multirow[b]{2}{*}{ Enzyme } & \multicolumn{3}{|c|}{1 month } & \multicolumn{3}{|c|}{6 months } \\
\hline & $\mathrm{S}^{\mathrm{a}}$ & $\mathrm{W} \& \mathrm{~S}^{\mathrm{b}}$ & $\mathrm{W}^{\mathrm{c}}$ & S & $\mathrm{W} \& \mathrm{~S}$ & W \\
\hline$\alpha$-D-Galactosidase & $\mathrm{nd}^{\mathrm{d}}$ & nd & $0.3 \pm 0.03^{\mathrm{e}}$ & nd & nd & $1.2 \pm 0.2$ \\
\hline$\beta$-D-Galactosidase & nd & nd & nd & nd & nd & $1.3 \pm 0.03$ \\
\hline$\alpha$-D-Glucosidase & nd & nd & $0.5 \pm 0.07$ & nd & $0.5 \pm 0.06$ & $2.5 \pm 0.09$ \\
\hline$\beta$-D-Glucosidase & $1.1 \pm 0.8$ & $2.1 \pm 1.7$ & $319.6 \pm 11.9$ & $0.1 \pm 0$ & $19.5 \pm 4.3$ & $615.8 \pm 36.4$ \\
\hline$\alpha$-D-Xylosidase & nd & nd & $1.3 \pm 0.04$ & nd & $0.3 \pm 0.08$ & $3.1 \pm 0.2$ \\
\hline
\end{tabular}

a : control medium (19) enriched with $0.2 \%$ glucose.

b W \& S: control medium enriched with $0.2 \%$ glucose and $1 \%$ wood.

c W: control medium enriched with $1 \%$ wood.

d nd: not detected.

e Three replicates were used for each measurement. Variance represents standard deviation.
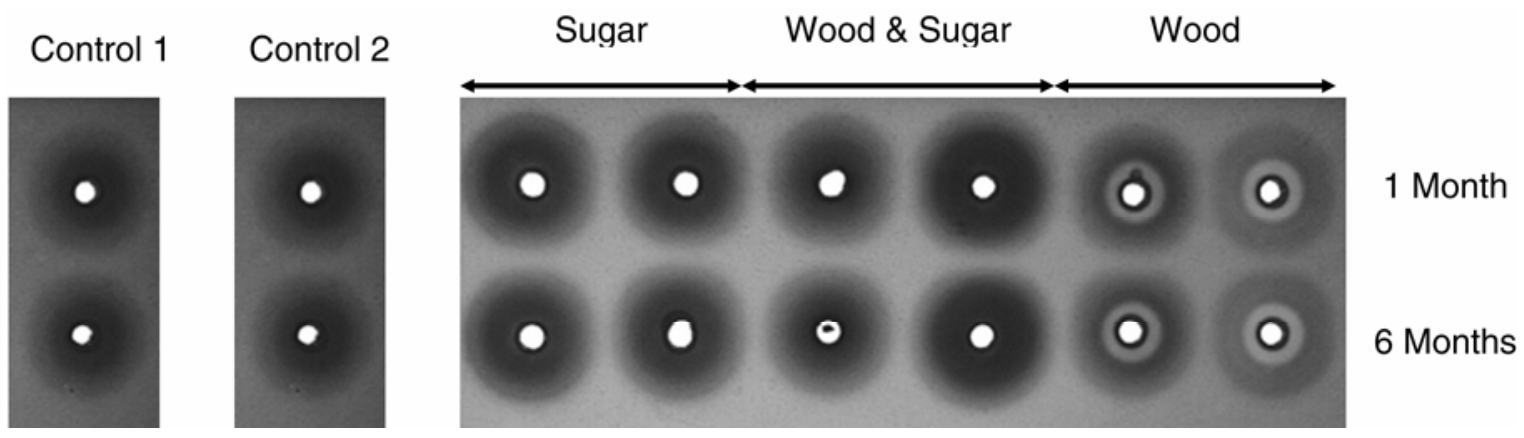

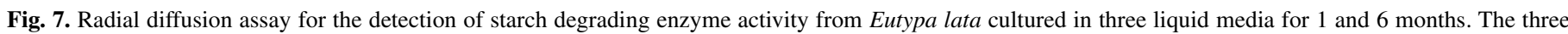

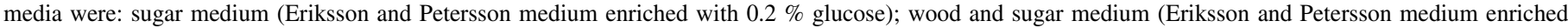

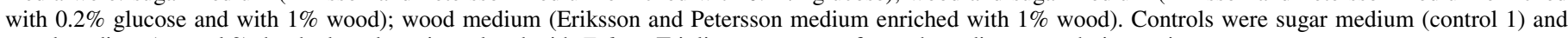
wood medium (control 2) that had not been inoculated with E. lata. Triplicates were run for each medium at each time point.

TABLE 3. Eutypa lata (isolate E31) secondary metabolites $(\mu \mathrm{g} / \mathrm{ml})$ produced after 1 and 6 months of growth in three liquid media

\begin{tabular}{|c|c|c|c|c|c|c|}
\hline \multirow[b]{2}{*}{ Secondary metabolite } & \multicolumn{3}{|c|}{1 month } & \multicolumn{3}{|c|}{6 months } \\
\hline & $\mathrm{S}^{\mathrm{a}}$ & $\mathrm{W} \& \mathrm{~S}^{\mathrm{b}}$ & $\mathrm{W}^{\mathrm{c}}$ & $\mathrm{S}$ & $\mathrm{W} \& \mathrm{~S}$ & W \\
\hline Eutypinol & $0.60 \pm 0.1^{\mathrm{d}}$ & $0.060 \pm 0.03$ & nd & $0.60 \pm 0.6$ & $\mathrm{nd}^{\mathrm{e}}$ & nd \\
\hline Eulatachromene & $0.06 \pm 0.01$ & nd & nd & $0.13 \pm 0.06$ & nd & nd \\
\hline Eutypine & $0.01 \pm 0.0$ & $0.003 \pm 0.001$ & nd & $0.10 \pm 0.0$ & nd & nd \\
\hline Eutypic acid & nd & nd & nd & $0.11 \pm 0.08$ & nd & nd \\
\hline
\end{tabular}

a : control medium (19) enriched with $0.2 \%$ glucose.

b W\&S: control medium enriched with $0.2 \%$ glucose and $1 \%$ wood.

c W: control medium enriched with $1 \%$ wood.

d Three replicates were used for each measurement. Variance represents standard deviation.

e nd: not detected. 
$(1,40)$. However the identification of starch-degrading activity in cultures supplemented with wood powder suggests that the starch is used to support the pathogen's energy needs. Therefore, starch could play a pivotal role as an energy reserve that could be used by the host and/or the pathogen.

The analysis of more soluble lower molecular weight carbohydrates in the water and water:methanol extracts of wood powder from the wood block experiment support the idea that there is a progressive utilization of starch and hemicellulosic wall polymers by E. lata. Over time, glucose-rich polymers are degraded to lower molecular weight sugars that become soluble. There is still glucose present in wood extracts at later time points. However, the content of xylose increases substantially during the first 6 months, a time during which hemicellulosic xylose is lost. The observation that xylose was more soluble at this time probably reflects a progression of breakdown events, including polymer solubilization and digestion, followed by utilization of the free sugar generated for energy metabolism by E. lata. The lack of accumulation of xylose and glucose in these soluble fractions over time indicates that the pathogen can utilize these sugars.

Our results also highlight the potential importance of lignin in the E. lata/grapevine interaction. A general defense response of trees to infection is compartmentalization where the host attempts to wall-off the invading agent by cell wall deposition of polyphenolic and polyaliphatic compounds such as suberin and lignin, and impede its spread within the water-conducting system by plugging the vessels with gums and tyloses $(35,38,39,40)$. We demonstrated higher levels of lignin in infected grape tissues, indicating that new lignin may be deposited in response to infection. Interestingly, lignin measured in the tolerant cv. Merlot was always quantitatively higher than the susceptible cv. Cabernet Sauvignon in all three wood zones. Higher phenolics were also measured in 1-year-old infected wood from cv. Merlot. Phenolic structure and composition may not explain tolerance of grapevine cultivars to E. lata, but it may certainly contribute to slowing the progression of the invading pathogen, as shown in other pathosystems $(38,39)$. Blanchette $(7)$ indicated that the erosion of the secondary walls by soft-rot fungi appears to be influenced by the type and the concentration of lignin: hosts with high lignin content with a lower syringyl/guaiacyl ratio are less susceptible to soft-rot than hosts with lower lignin content and a higher syringyl/guaiacyl ratio. However, no qualitative measurements were made of the type of lignin produced by cvs. Merlot and Cabernet Sauvignon.

The dynamic balance between lignin synthesis, perhaps as a defense response, and lignin breakdown in $E$. lata-infected grapevines can only be inferred from our data. The pathogen's progressive breakdown of cell wall material as lesions expand could support the idea that its use of wall- and starch-derived carbohydrate leads to an increase in relative lignin content of wood powders with no actual absolute increase in lignin amount. In the grape wood block experiment, the wood was autoclaved before inoculation, thus no synthesis and deposition of lignin was possible. After 6 months of pathogen development wall-bound lignin was clearly degraded. In the 12- and 18-month samples, the increase in relative lignin indicates a decrease in the breakdown of lignin as breakdown of the glucose- and xylose-containing wood components continues. In the later stage of the wood block experiment the combined data for loss in wood dry mass (Fig. 3) and wood powder lignin content (data not shown) indicate an absolute increase in lignin content (Fig. 5). This may suggest a decrease in the relative contribution of $E$. lata mycelium to the dry mass of the wood samples over time, the pathogen consuming its own biomass as pycnidia form. In fact, at the 18 months sampling time, visible mycelium was not evident in collected blocks, while pycnidia represented the only apparent fungal structures.

Here, we identified several enzymes potentially involved in the breakdown of hemicellulose and lignin. E. lata was previously reported to possess lignolytic activity (17) and to produce hydrolytic enzymes (37), and our results support those findings. The fungus produced phenol oxidases that might participate in the breakdown of wall-bound lignin. Moreover, E. lata expressed several hydrolytic enzymes of polysaccharide substrates, including some glycosidases not previously reported. Nonetheless, more work should be undertaken to characterize the full spectrum of E. lata cell wall degrading enzymes involved in the breakdown of lignocellulosic material.

In liquid cultures, the presence of free glucose in the culture medium repressed glycosidase production. This enzymatic repression has also been reported with other wood decay fungi when grown in liquid media in the presence of free glucose $(21,22,37)$. This mechanism is known as "glucose repression" and is thought to be an energy-saving response as it primarily affects enzymes used to metabolize other carbon sources, which are dispensable in the presence of readily metabolizable glucose (34). The disappearance or absence of free glucose in E. lata liquid cultures resulted in an increase in expression of most of the enzymes that were assayed. This may explain the fact that glucose present in cell wall glucans and starch stored in xylem parenchyma cells appears to be metabolized early by E. lata, while the breakdown of xylose-containing polymers, as judged by the accumulation of soluble xylose in wood powder extracts, is slower. The liquid culture data also support the conclusion that E. lata is able to sense the presence of the wood powder substrate, including the starch component, and produce the enzymes required to utilize these more complex sources of carbohydrate when free glucose is not present or falls below the level required for suppression of enzyme production.

In contrast, $E$. lata's production of secondary metabolites was not affected by glucose repression. E. lata metabolites were expressed after 1 month in glucose-rich liquid cultures but not in the glucose-free medium. The metabolites that accumulated in the culture media were different both in quality and quantity than in our previous reports with $E$. lata isolate E31 $(26,32)$. In the control wood-free medium, the growth of E. lata was very slow, much slower than the hot water medium used in previous studies, which may have limited the quantitative production of metabolites. Also the type of medium used here was different from that in previous studies, which led to the production of eutypic acid and the absence of methoxyeutypinol, siccayne, and eulatinol by E. lata isolate E31. Mahoney et al. (25) demonstrated that different media had an impact on qualitative and quantitative production of those metabolites, which could explain the variability in the metabolite production observed with isolate E31. In the woodenriched media, the fungal growth was enhanced, but the metabolites did not accumulate over time, suggesting that their binding to wood substrate may have occurred or that they were metabolized further and not detected. If further analyses, now underway, confirm the binding of these metabolites to the wood, this major finding will refute the current hypothesis of free circulation of secondary metabolites in planta. E. lata is present in the cordon and spurs of infected grapevines and its metabolites are known to be phytotoxic to grapevine cells $(13,35,42)$. Tey-Rulh et al. (44) detected eutypine in the inflorescence and sap of infected plant material. This led to the conclusion that E. lata metabolites were transported to the herbaceous tissues by the transpiration stream resulting in the diseased appearance of these tissues. However, our repeated attempts to identify any phytotoxic metabolite in symptomatic tissues or sap were unsuccessful (26; P. E. Rolshausen, unpublished data).

More studies are needed to determine the role of starch stored in woody grapevine tissues in disease development. Is the readily used starch energy source a factor that supports the establishment of E. lata infection? What enzymes does the pathogen use to harvest the glucose in starch? Xylose- and glucose-containing hemicelluloses are degraded as infection develops. What are the 
structures of the targeted polysaccharides and what are the enzymes that initiate this cell wall breakdown? Do woody grapevine tissues incorporate newly synthesized lignin into their cell walls in response to infection and what are the enzymes used by E. lata to digest lignin barriers? What is the role that fungal phytotoxins play in the expression of the disease? While these questions should be answered, the present study have established a better understanding of the virulence factors expressed by $E$. lata to cause disease in grapevine and has characterized the cell wall fractions targeted during fungal attack and the wall degradation products that provide substrates for E. lata's energy metabolism.

\section{ACKNOWLEDGMENTS}

This work was supported in part by the American Vineyard Foundation and the Viticulture Consortium West. We thank C. Janousek (University of California, Davis) for his advice in statistical analyses.

\section{LITERATURE CITED}

1. Adaskaveg, J. E., Blanchette, R. A., and Gilbertson, R. L. 1991. Decay of date palm wood by white-rot and brown-rot fungi. Can. J. Bot. 69:615629.

2. Ahmed, A. E. R., and Labavitch, J. M. 1977. A simplified method for accurate determination of cell wall uronide content. J. Food Biochem. 1:361-365.

3. Albersheim, P., Nevins, D. J., English, P. D., and Karr, A. 1967. A method for the analysis of sugars in plant cell wall polysaccharides by gas liquid chromatography. Carbohyd. Res. 5:340-345.

4. Alfonso, C., Santamaria, F., Nuero, O. M., Prieto, A., Leal, J. A., and Reyes, F. Biochemical studies on the cell wall degradation of Fusarium oxysporum $\mathrm{f}$. $\mathrm{sp}$. lycopersici race 2 by its own lytic enzymes for its biocontrol. Lett. Appl. Microbiol. 20:105-109.

5. Bavendamm, W. 1928. Über das vorkommen und den nachweis von oxydasen bei holzzerstörenden pilzen. Z. Pflanzenk. Pflanzen. 38:257276.

6. Blackeney, A. B., Harris, P. J., Henry, R. J., and Stone, B. A. 1983. A simple and rapid preparation of alditol acetates for monosaccharides analysis. Carbohyd. Res. 113:291-299.

7. Blanchette, R. A. 1995. Degradation of the lignicellulose complex in wood. Can. J. Botany 73:S999-S1010.

8. Blumenkrantz, N., and Asboe-Hansen, G., 1973. New method for quantitative determination of uronic acids. Anal. Biochem. 54:484-489.

9. Bull, A. T. 1970. Chemical composition of wild-type and mutant Aspergillus nidulans cell walls. The nature of polysaccharide and melanin constituent. J. Gen. Microbiol. 63:75-94.

10. Carter, M. V. 1957. Eutypa armeniacae Hansf. \& Carter, sp. nov., an airborne vascular pathogen of Prunus armeniaca L. in Southern Australia. Aust. J. Bot. 5:21-35.

11. Carter, M. V., Bolay, A., and Rappaz, F. 1983. An annotated list and bibliography of Eutypa armeniacae. Rev. Plant Pathol. 62:251-258.

12. Carter, M. V., and Moller, W. J. 1977. Eutypa canker and dieback of apricots. Eur. Mediter. Plant Prot. Org. Bull. 7:85-94.

13. Deswarte, C., Canut, H., Klaebe, A., Roustan, J. P., and Fallot, J. 1996. Transport, cytoplasmic accumulation and mechanism of action of the toxin eutypine in Vitis vinifera cells. J. Plant Physiol. 149:336-342.

14. Dische, Z. 1962. Color reactions of carbohydrates. Pages 475-514 in: Methods in Carbohydrate Chemistry. R. L. Whistler and M. L. Wolfram, eds. Academic Press, New York.

15. Doster, M. A., and Bostock, R. M. 1988. Effects of low temperature on resistance of almond trees to Phytophthora pruning wound cankers in relation to lignin and suberin formation in wounded bark tissue. Phytopathology 78:478-483.

16. Dubos, B. 1987. Mise au point sur les maladies de deperissement dans le vignoble Francais. Le Progres Agricole et Viticole. 104:135-140.

17. Elghazali, B., Gas, G., and Fallot, J. 1992. Biodegradation des lignocelluloses de vigne (Vitis vinifera cv. Cabernet Sauvignon) par Eutypa lata (Pers. Fr.). Tul. Vitis 31:95-103.

18. English, H., and Davis, J. R. 1978. Eutypa armeniacae in apricot: Pathogenesis and induction of xylem soft-rot. Hilgardia 46:193-204.

19. Eriksson, K. E., and Petersson, B. 1975 Extracellular enzyme system utilized by the fungus Sporotrichum pulverulentum (Chrysosporium lignorum) for the breakdown of cellulose. Eur. J. Biochem. 51:193-206.

20. Eslyn, W. E., Kirk, T. K., and Effland, M. J. 1975. Changes in the chemical composition of wood caused by six soft-rot fungi. Phytopathology 65:473-476.
21. Galhaup, C., Wagner, H., Hinterstoisser, B., and Haltrich, D. 2002. Increased production of laccase by the wood-degrading basidiomycete Trametes pubescens. Enzyme Microbiol. Technol. 30:529-536.

22. Gomes, D. J., Gomes, J., and Steiner, W. 1994. Factors influencing the induction of endo-xylanase by Thermoascus aurantiacus. J. Biotechnol. 33:87-94.

23. Greve, L. C., Labavitch, J. M., Stack, R. J., and Hungate, R. E. 1984. Muralytic activities of Ruminococcus albus 8. Appl. Environ. Microbiol. 47:1141-1145.

24. Guest, G. M., and Momany, M. 2000. Analysis of cell wall sugars in the pathogen Aspergillus fumigatus and the saprophyte Aspergillus nidulans. Mycologia 92:1047-1050.

25. Mahoney, N., Lardner, R., Molyneux, R. J., Scott, E. S., Smith, L. R., and Schoch, T. K. 2003. Phenolic and heterocyclic metabolite profiles of the grapevine pathogen Eutypa lata. Phytochemistry 64:475-484

26. Mahoney, N., Molyneux, R. J., Smith, L. R., Schoch, T. K., Rolshausen, P. E., and Gubler, W. D. 2005. Dying-arm disease in grapevines: Diagnosis of infection with Eutypa lata by metabolite analysis. J. Agric. Food Chem. 53:8148-8155.

27. Martin, J. A., Solla, A., Coimbra, M. A., and Gil, L. 2005. Metabolic distinction of Ulmus minor xylem tissues after inoculation with Ophiostoma novo-ulmi. Phytochemistry 66:2458-2467.

28. Martinez, A. T., Speranza, M., Ruiz-Dueñas, F. J., Ferreira, P., Camarero, S., Guillén, F., Martinez, M. J., Gutiérrez, A., and del Rio, J. C. 2005. Biodegradation of lignocellulosics: Microbial, chemical, and enzymatic aspects of the fungal attack of lignin. Int. Microbiol. 8:195-204.

29. Mauro, M. C., Vaillant, V., Tey-Rulh, P., Mathieu, Y., and Fallot, J. 1988. In vitro study of the relationship between Vitis vinifera and Eutypa lata (Pers.:Fr.) Tul. Demonstration of toxic compounds secreted by the fungus. Am. J. Enol. Viticult. 39:200-204.

30. Munkvold, G. P., Duthie, J. A., and Marois, J. J. 1994. Reductions in yield and vegetative growth of grapevines due to Eutypa dieback. Phytopathology 84:186-192.

31. Peros, J. P., Berger, G. 1994. A rapid method to assess the aggressiveness of Eutypa lata isolates and the susceptibility of grapevine cultivars to Eutypa dieback. Agronomie 14:515-523.

32. Rolshausen, P. E., Mahoney, N., Molyneux, R. J., and Gubler, W. D. 2006. A re-assessment of the species concept in Eutypa lata, the causal agent of Eutypa dieback of grapevine. Phytopathology 96:369-377.

33. Rolshausen, P. E., Trouillas, F. P., and Gubler, W. D. 2004. Identification of Eutypa lata by PCR-RFLP. Plant Dis. 88:925-929.

34. Ronne, H. 1995. Glucose repression in fungi. Trends Genet. 11:12-17.

35. Rudelle, J., Octave, S., Kaid-Harche, M., Roblin, G., and Fleurat-Lessard, P. 2005. Structural modifications induced by Eutypa lata in the xylem of trunk and canes of Vitis vinifera. Funct. Plant Biol. 32:537-547.

36. Savory, J. G. 1954. Breakdown of timber by ascomycetes and fungi Imperfecti. Ann. Appl. Biol. 41:336-347.

37. Schmidt, C. S., Wolf, G. A., and Lorenz, D. 1999. Production of extracellular hydrolytic enzymes by the grapevine dieback fungus Eutypa lata. J. Plant Dis. Prot. 106:1-11.

38. Shain, L. 1979. Dynamic responses of differentiated sapwood to injury and infection. Phytopathology 69:1143-1151.

39. Shigo, A. L. 1984. Compartmentalization: A conceptual framework for understanding how trees grow and defend themselves. Annu. Rev. Phytopathol. 22:189-214.

40. Shigo, A. L., Gregory, G. F., Campana, R. J., Dudzik, K. R., and Zimel, D. M. 1986. Patterns of starch reserves in healthy and diseased American elms. Can. J. For. Res. 16:204-210.

41. Siebert, J. B. 2001. Eutypa: the economic toll on vineyards. Wines Vines 50-56.

42. Smith, L. R., Mahoney, N., and Molyneux, R. 2003. Synthesis and structure- phytotoxicity relationships of acetylenic phenols and chromene metabolites, and their analogues, from the grapevine pathogen Eutypa lata. J. Nat. Prod. 66:169-176.

43. Taylor, R. J. and Secor, G. A., 1988. An improved diffusion assay for quantifying the polygalacturonase content of Erwinia culture filtrates. Phytopathology 78:1101-1103.

44. Tey-Rulh, P., Philippe, I., Renaud, J. M., Tsoupras, G., De Angelis, P., Fallot, J., and Tabacchi, R. 1991. Eutypine, a phytotoxin produced by Eutypa lata the causal agent of dying-arm disease of grapevine. Phytochemistry 30:471-473.

45. Vicente, A. R., Powell, A., Greve, L. C., and Labavitch, J. M. 2007. Cell wall disassembly events in boysenberry (Rubus ideaus L. x Rubus ursinus Cham. \& Schldl.) fruit development. Funct. Plant Biol. 34:614623.

46. Worall, J. J., Anagnost, S. E., and Zabel, R. A. 1997. Comparison of wood decay among diverse lignocolous fungi. Mycologia 89:199-219.

47. Zapata, C., Deléens, E., Chaillou, S., and Magné, C. 2004. Partitioning and mobilization of starch and $\mathrm{N}$ reserves in grapevine (Vitis vinifera $\mathrm{L}$.). J. Plant Physiol. 161:1031-1040. 